The Question of Access to the Japanese Market

Peter Drysdale

Working Paper No. 97

Peter Drysdale is Professor and Executive Director of the Australia-Japan Research Centre, Research School of Pacific and Asian Studies, The Australian National University

\author{
Working Paper Series \\ Center on Japanese Economy and Business \\ Graduate School of Business \\ Columbia University
}

August 1995

This paper will be published in the Economic Record, Vol. 71, No. 214

September 1995, pp. 266-278 


\section{The Question of Access to the Japanese Market ${ }^{1}$}

The question of access to the Japanese market has again become a central issue in the high politics of the relationship between the world's two largest economies. The settlement of the impasse over automobile and automobile parts trade (Hashimoto and Kantor, 28 June 1995) within the context of the Framework Agreement talks between the United States and Japan, has not resolved the issue - rather it underlines the continuing importance in American thinking of new trade policy strategies towards Japan and, perhaps, more broadly the whole of East Asia.

Of course, Japan still has an agricultural sector which is among the most highly protected in the world, and Japanese agricultural protection for those commodities, like rice, the import of which is subject to quantitative restriction, rose rapidly over the last two decades of yen appreciation at a time when, otherwise, Japanese commercial policy was pointed towards trade liberalisation. ${ }^{2}$

Restrictions on a whole range of service trades are also pervasive, from construction and civil aviation to legal services. These restrictions are a prime target of the stalled reform package introduced by former Prime Minister Hosokawa in $1993 .^{3}$

\footnotetext{
${ }^{1}$ I am grateful to John Kunkel for assembling all the bibliographical material on which this paper is based and for other assistance in its preparation. I am also grateful to Paul Sheard, Ross Garnaut, Ben Smith, Luke Gower, Tony Warren, Gordon de Brouwer, and Bill Norton for comments on a draft. I alone, of course, am responsible for the final form of the argument.

${ }^{2}$ In this respect, Japan is, of course, only a front runner among the industrial country pack and even in agriculture, the liberalisation of the beef market in Japan after 1988 represents among the most significant agricultural trade liberalisations by any industrial country in recent times. At last, there is also a narrow opening in the rice market under the Japanese government's Uruguay Round commitments.

${ }^{3}$ Yet, in this sector too, the barriers are on the way down and, insofar as it is possible to devise objective measures of services trades affected by the regulatory system, Japan is not so far behind the United States in the openness of its services markets to foreign competition (see table below).

The table provides a number of measures of the extent to which APEC economies have not committed to liberal trade under the GATS. The most important finding is that listed for all commitments. This is the average level of impediments for each country across all industries and all modes. The United States is
} 
Ostensibly, Japan has the cleanest import system for manufactured goods among virtually all OECD countries: on average tariffs are lower and official non-tariff barriers have almost no effect on trade at all. Moreover, Japan, like Australia, is not a participant

the most liberal in terms of this score, Japan is second and Australia is third. It is interesting to note that Japan is the most liberal in terms of market access, the US in terms of national treatment.

Table 1 Measures of the Frequency of Application of Restrictions on Services Trade for APEC Countries ${ }^{\text {a }}$

\begin{tabular}{lccccccc}
\hline & $\begin{array}{c}\text { All } \\
\text { Commitments }\end{array}$ & Market Access & $\begin{array}{c}\text { National } \\
\text { Treatment }\end{array}$ & Mode 1 & Mode 2 & Mode 3 & Mode 4 \\
& & & & & & & \\
\hline Australia & 49.6 & 49.5 & 49.7 & 46.5 & 43.0 & 40.4 & 68.6 \\
Brunei & 95.0 & 95.7 & 94.3 & 94.9 & 93.2 & 95.9 & 96.2 \\
Canada & 61.2 & 62.1 & 60.2 & 58.6 & 53.0 & 58.1 & 75.0 \\
Chile & 90.2 & 90.3 & 90.1 & 91.1 & 92.5 & 85.3 & 91.8 \\
China & 88.2 & 88.5 & 87.9 & 96.8 & 78.7 & 90.6 & 86.7 \\
Hong Kong & 88.1 & 83.4 & 92.8 & 97.7 & 85.1 & 71.9 & 97.6 \\
Indonesia & 91.6 & 91.0 & 92.2 & 91.2 & 89.8 & 92.7 & 92.8 \\
Japan & $\mathbf{4 6 . 5}$ & $\mathbf{4 4 . 0}$ & $\mathbf{4 8 . 9}$ & $\mathbf{3 8 . 8}$ & $\mathbf{3 1 . 3}$ & $\mathbf{4 7 . 5}$ & $\mathbf{6 8 . 4}$ \\
Korea, Rep & 70.7 & 75.1 & 66.2 & 70.7 & 67.4 & 65.0 & 79.5 \\
Malaysia & 78.8 & 80.4 & 77.2 & 74.9 & 74.0 & 80.3 & 86.1 \\
Mexico & 71.9 & 74.1 & 69.7 & 73.0 & 62.3 & 70.8 & 81.5 \\
New Zealand & 56.6 & 56.4 & 56.8 & 50.7 & 49.0 & 51.1 & 75.7 \\
Philippines & $\mathbf{8 0 . 8}$ & 82.2 & 79.4 & 81.9 & 79.6 & $\mathbf{8 1 . 4}$ & $\mathbf{8 0 . 3}$ \\
Singapore & $\mathbf{8 2 . 0}$ & 80.2 & 83.7 & 80.8 & 74.2 & 79.6 & 93.3 \\
Thailand & 77.3 & 79.2 & 75.4 & 92.8 & 59.7 & 79.1 & 77.7 \\
United States & $\mathbf{4 3 . 0}$ & $\mathbf{4 6 . 3}$ & $\mathbf{3 9 . 7}$ & $\mathbf{3 7 . 9}$ & $\mathbf{3 9 . 1}$ & $\mathbf{4 2 . 2}$ & $\mathbf{5 2 . 9}$ \\
& & & & & & & \\
\hline
\end{tabular}

Notes: $a$ The ratios reported in this table represent the frequency with which a country has failed to commit to liberal trade measures under the General Agreement on Trade in Services (GATS). The higher the number, the more the restrictions.

$b$ Each mode represents a different way for services to be transacted internationally.

Mode 1 = cross-border supply; Mode 2 = consumption abroad; Mode 3 = commercial presence; Mode $4=$ presence of persons.

Source: Tony Warren, The Political Economy of Services Trade Policy: Australia, Japan and the United States (PhD Thesis ANU, forthcoming). 
in the Multi Fibres Arrangement (MFA) so that its market for the most important labourintensive exports from developing economies is more open than that of all other large industrial countries. Thus far, Japan has largely resisted the temptation of seeking 'voluntary export restraint' on this sensitive area of manufactured goods trade.

Paradoxically, it is in manufactured goods trade - the heartland of Japan's industrial competitiveness - that the question of access to the Japanese market now looms largest. There may be few official barriers to trade in manufactured goods, but the import share in Japanese markets is low in comparison with other industrial countries (Lawrence, 1987; Balassa and Noland, 1988) and it is frequently argued that non-official barriers limit access to the Japanese market for these goods. 'Hidden barriers' to trade, the argument runs, are endemic in Japanese corporate organisation and business structures and the 'peculiar' features of the Japanese market effectively exclude foreign competition.

This survey focuses on the question of how market structure and different corporate organisational forms might affect access to the Japanese market for industrial goods. The question is how and whether keiretsu corporate structures in Japan constitute an important unofficial barrier in access to the Japanese market for manufactured goods. This is an important issue.

The premise that 'hidden' barriers to trade explain Japan's low manufactured goods trade shares and international price differentials has gained currency in policy circles and come to provide a rationale for so called 'results-oriented' trade strategies. These including the application of Section 301 (of the 1974 United States Trade Act) (Robinson and Houghton, 1989) and attempts to set numerical import targets, sector by sector, for the volume of American goods that Japan and (potentially) other foreign countries are expected to buy (Passell, 1989; Altman, 1994; Bergsten and Noland, 1993; Bhagwati, 1994).

The latest and most threatening expression of this thinking was in the contretemps between the United States and Japan over the American share of the Japanese automobile market (Kantor, 1995b; Clinton, 1995). 
First, I review briefly the literature which contests the importance of Japanese barriers to trade in manufactured goods. Then, I explore the link between corporate structures and closed markets, identifying two analytically separate arguments which suggest that keiretsu corporate structures exclude foreign competition in the market for manufactures. Three types of keiretsu corporate structure are defined - financial keiretsu, vertical keiretsu, and distribution keiretsu. All are vertical organisational structures, in the sense of the literature on industrial organisation. I explore the argument that these structures are 'anti competitive' and that they constitute a 'hidden barrier' to trade. I draw attention to a study of Japanese investment in Australia which has been cited widely as evidence of the closedness of Japanese markets. Finally, I review the implications for policy.

Many other facets of developments in trans-Pacific economic diplomacy are worthy of review - the macro-economic context which has brought the bilateral trade balance into sharp political focus in the United States; Japan's trade and current account surpluses, as a lightning rod for tensions in the management of the relationship with the United States; the dynamics of trade and foreign economic policy developments between Japan and the United States; the transition in the structure of economic power in Asia and the Pacific and its impact on policy substance and posture; the effect of these trends in trade policy between the two largest economic powers on the international trade policy environment. Some of these issues I have reviewed elsewhere (Drysdale, 1989).

But understanding whether keiretsu corporate structures constitute a 'hidden barrier' to trade is central to assessment of the strength of the intellectual foundations, and therefore of the good sense, of the new trade policy strategies towards Japan. That is not to say, of course, that the strategies would have no impact even if they were premised on false intellectual foundations. As always, the question is whether they are likely to contribute to international welfare, not just redistribute income, for example, in favour of particular American producers and factors of production. There is also a broader scholarly interest in the effect of corporate organisational structures on the nature and operation of 
international markets - a big question which is illuminated somewhat, but is not in the spotlight of attention in the literature surveyed here.

\section{Barriers to trade in manufactures}

A number of studies have explored the low propensity in Japan to import manufactured goods and sought to confirm the contention that Japanese institutions, or reliance on a variety of informal barriers to trade is its cause (Balassa, 1986; Lawrence, 1987; Balassa and Noland, 1988; Krugman, 1991; Lawrence, 1991a; Fung, 1991; Lawrence, 1991b; Bergsten and Noland, 1993). These studies compare Japan's imports of manufactured goods with those of other industrial countries and conclude that Japan is an 'outlier', with a lower share of manufactured goods imports and intra-industry trade in this sector. On the other hand, evidence provided by other studies of Japan's trade dependence and trade structure, such as those of Saxonhouse (1986), Saxonhouse (1988, esp. p.240), Saxonhouse and Stern (1989), Goto, F (1991), Weinstein and Yafeh (1993), and Saxonhouse (1993) suggests that there is no significant difference between Japan's trade structure and that of other industrial countries, when account is taken of cross-national differences in factor endowments, including capital, labour and a variety of natural resources, as well as distance in the international marketplace.

Sazanami, Urata and Kawai (1995) attempt to overcome the problems associated with 'indirect' assessment of the barriers to Japanese imports of manufactured goods by measuring directly the price wedge between Japanese products and similar imported goods. There have been other price comparison studies but they are far less rigorous (US Department of Commerce and Japan Ministry of International Trade and Industry, 1989). Very few countries collect data that allow ex-factory prices to be compared directly with the import prices of 'comparable' products at the required level of disaggregation; Japan is one of them. Unit value (price) differences are assumed to reflect the effect of official barriers to trade - which are measurable or observable - or non-official 'hidden' barriers to trade. Studies of differentials over time would be more robust to this criterion. 
Although Sazanami, Urata and Kawai (1995, p.14) exclude 26 product categories (among them automobiles) from their study because of product heterogeneity revealed in sensitivity analysis of the data, their findings reveal large differentials in the prices of 'comparable' domestically produced and imported products. These differentials reflect official barriers to trade (272.5 per cent for the food and beverages product category) but, in other cases are not satisfactorily explainable by official barriers to trade (34.5 per cent for cotton yarn and 282.2 per cent for clothing) and are attributed to 'hidden' or nonofficial barriers to trade. While the authors are careful not to attribute these measured price differences to Japanese corporate practices, their evidence has been used with less caution to support the interpretation that corporate practices in Japan are their cause (Bergsten and Noland, 1993, pp. 279-297).

There are two significant problems with this study, despite its being the most comprehensive and rigorous of its kind thus far. First, as Sazanami, Urata, and Kawai admit (1995, p.12), there is a real question about whether like is being compared with like in the price comparisons. Take the case of clothing product price comparisons. There are substantial quality differences between clothing made in Japan and imported clothing from China and other developing economies (which constitute the bulk of imports in this category). Imports service a different segment of the market for clothing from Japanese made clothing. The price differential for this product category is not a credible measure of the difference in price of the same goods produced domestically and produced abroad. Even for foodstuffs, the problem of matching product categories is serious: 12 canned and bottled Japanese products are 'matched' with 42 imported items (p.8), but how can they be, reliably? Second, there is the endemic problem with studies of this kind (Kravis, and Lipsey, 1971 pp.42-43) that measure price differentials. Such studies reflect continuous disturbance and adjustment in dynamic markets (the forces of competition itself) at least as much as, and probably more than, the presence of restrictions - official or non-official in the market.

This problem is extreme in a study which seeks to measure price differences between Japanese products and imported products in the period 1985, and uses price 
indices to project differentials in 1989, (a period over which there was a sharp appreciation of the Japanese currency and huge change in the structure of Japanese trade), the share of manufactured goods imports almost doubling during this period (Drysdale, 1989). These elementary practical and analytical issues are also ignored in other studies which interpret price differentials as evidence of 'hidden' barriers to trade and relate these barriers to Japanese corporate practice (Krugman, 1991; Lawrence, 1993).

\section{Corporate structure and closed markets}

The idea that keiretsu corporate structures in Japan are associated with 'closed' Japanese markets has wide currency in American policy and business circles (ACTPN 1993, USTR 1995; Bergsten and Noland, 1993).

There are two elements in the idea. The first is that Japanese corporate organisational structures facilitate collusion and predatory pricing behaviour in Japanese markets and internationally. Cartels and collusive trade practices constitute barriers to entry and an 'unfair' impediment to trade. The second analytically separable element relates to the nature of inter-firm ties and relational transactions which appear to typify manufacturing assembly in Japan. Dore (1986, p. 248) makes the point: 'Imports penetrate into markets, and where there are no markets, only a network of established "customer relationships", it is hard for them to make headway'. An ancillary issue is the 'exclusionary' system whereby intermediate and final products are distributed in the Japanese market.

Monopolistic behaviour, were it distinctively prevalent, would certainly limit market access. And undoubtedly there are markets in Japan in which monopolistic behaviour is a concern, such as construction or glass (McMillan, 1990; Sazanami, Urata and Kawai, 1995). But the question is whether keiretsu corporate structures can be presumed synonymous with monopolistic behaviour as the first element in the idea that Japanese corporate structures serve to close markets suggests.

Access to markets which are 'closed' because they are internalised through the vertical integration of firms (historically a common pattern in the United States) or 
because they are characterised by long term contracting, relational dealings or 'partial' vertical integration (the pattern observed more commonly in Japan) is another matter altogether. How such market structures are ordered reflects the choice of firms in defining the boundaries of their operations (Coase, 1937; Williamson, 1975; Alchian and Demsetz, 1972; Jensen and Meckling, 1976; Fama, 1980; Cheung, 1983; Williamson, 1985; Sheard, 1993; Sheard 1994). It is not clear that there is a policy role in which competitive pressures encourage that this choice be made efficiently. Firms (both domestic and foreign) have a strategic interest in how other firms make the choice about the boundaries of their operations but government intervention in this area is more likely to reduce efficiency and welfare than to enhance it.

Keiretsu may be associated with 'closure of markets' in the sense that the location and nature of transacting at the boundaries of intermediate product markets is endogenously determined in the organisation of industry; but this is a completely different sense of closure from its meaning in the context of trade policy where closure results from exogenously imposed trade barriers.

In policy discussion the two elements in the idea that keiretsu corporate structures exclude foreign competition are routinely confused. There is also some confusion in the academic literature, especially that which relies on secondhand knowledge of the institutions and how they operate. The language of trade practices and competition policy - collusion, exclusionary practices, closed markets - is applied indiscriminately and inappropriately to both elements in the idea. The first step is to clarify the nature of keiretsu corporate structures to establish a sounder foundation for the analysis of their impact on access to the Japanese market.

This is not so simple a task as it may seem. Others (Saxonhouse, 1993; Sheard, 1994) have observed that, even in technical discourse, the term keiretsu is used loosely in Japan to describe a wide range of corporate affiliations and the corporate groups which they define. There is an endless literature in Japanese (Sheard, 1986) and a growing literature in English which helps to clarify the issues (Goto, A, 1982; Abbeglen and Stalk, 
1985; Sheard, 1991; Saxonhouse, 1991; Gerlach, 1992; Fruin, 1992; Gibson and Roe, 1993; Saxonhouse, 1993; Aoki, Patrick and Sheard, 1994; Sheard, 1994).

Sheard (1994) distinguishes three kinds of keiretsu structures. The first - financial keiretsu - comprises corporate groups, each representative of a wide range of industrial sectors and associated through cross-shareholdings and financial transactions with one of Japan's major city (or commercial) banks. There are six main-bank corporate groups Mitsui, Mitsubishi, Sumitomo, Fuji (deriving from the prewar zaibatsu), Sanwa and Daiichi Kangyo (formed in the high growth period after the war). These keiretsu groups are linked through financing relationships with the main bank and other financial institutions, interlocking shareholdings, association with a general trading company, supply relationships, and membership in one or more 'presidents' clubs, which provide an opportunity for senior management to meet regularly. Only 8 percent of listed firms on the Tokyo Stock Exchange belong to these clubs but the source used by Sheard (Keizai Chosa Kyokai, 1992) classifies 59 percent of non-financial firms listed on the exchange as being affiliated in some way with one or another of these main-bank groups. The average level of the intra-group shareholding of these groups is around 18 percent, so too is the average level of intra-group bank and insurance financing. On average only 9 percent of purchases and 8 percent of sales are with other group firms, although for the general trading companies intra-group business is as high as two thirds of total business (Sheard, 1994, pp. 8-9). Financial keiretsu are vertical structures, in the sense of the literature on industrial organisation. Main-bank and co-insurance networks resemble a partially internalised capital market and the vertical linkages prominent in vertical keiretsu in intermediate commodity markets.

The second - vertical keiretsu - comprise large assembly and manufacturing firms and their networks of subsidiaries and affiliated suppliers upstream in the production chain. Toyota is typical in the automobile industry. Matsushita, Hitachi, and Toshiba are typical in the electrical goods industry. Sheard (1994, p.9) identifies 40 major 'pyramidstyle') keiretsu groups like this, each with an average of over 190 subsidiaries or associated companies (Toyo Keizai Shimposha, 1991, p.54). One study of Toyota 
affiliates identifies 168 first-tier suppliers with, in turn, 5437 indirect or second-tier suppliers and a further 41,702 lower level or third-tier suppliers (Fruin, 1992, p.271). Toyota's 41 most important direct suppliers and subcontractors, for example, accounted for 75 percent of total inputs in 1991. These firms are not totally dependent on Toyota, which on average held about 25 percent of their shares and accounted for around 43 percent of their sales (Sheard, 1994, pp. 10-11, 44-45).

The third - distribution keiretsu - also involves vertical ties, but downstream in the production and distribution process, not upstream as in the case of vertical keiretsu. Most large firms have some kind of distribution system. Affiliated dealer networks or chain store outlets are common in final goods markets. The nine Japanese passenger vehicle producers, for example, have almost 4,000 affiliated leaders and over 17,000 outlets. In many cases the dealerships are exclusive, but producer-ownership links vary considerably. For intermediate products 'special agency contracts', management and other assistance to agents is common (Sheard, 1994, pp.11-12).

These three types of keiretsu structure are not mutually exclusive. As Sheard (1994, p.13) points out, 'leading industrial firms in financial keiretsu are typically parent firms in their own supplier networks, distribution networks and subsidiary groups.' Clearly keiretsu membership cannot be defined on a single dimension and it is much more ambiguous even than this helpful taxonomy suggests.

Saxonhouse (1993, p.37) draws attention to the variety of definitions of keiretsu and consistent classification systems available from Japanese sources. Dodwell Marketing Group, Nihon Keizai Shimbunsha, Toyo Keizai Shimposha, Keizai Chosa Kyokai are four of the most prominent sources and data from these sources can differ widely. Weinstein and Yafeh (1993) show that none of the five most commonly used definitions are closely correlated (the highest coefficient being 0.32) and Saxonhouse (1993, p.37) points out that classifications change arbitrarily even in the one source year by year. The Dodwell Marketing Group classification, on which Lawrence (1991a) bases his work, lists 9 vertical keiretsu in 1986, but three years later the number jumps to 33. Arbitrary 
classification is obviously a product of different understandings of the nature of keiretsu and muddies analysis of their role in the operation of the Japanese economy.

On top of the problem of the classification of keiretsu structures, Japanese firms consistently change their corporate affiliations, much more frequently than is generally understood. Horiuchi, Packer and Fukuda (1988) report that more than 25 percent of firms listed on the Tokyo Stock Exchange changed their main-bank or financial keiretsu affiliation between the 1970s and 1980s. Keiretsu corporate structures are clearly a more plastic economic variable than many research analysts and most policy commentators realise.

However, suppose that keiretsu affiliations can be described unambiguously in the three dimensions set out by Sheard (1994). At least at one point in time, using the one data source (Sheard chose Keizai Chosa Kyokai) this is practicable. What are their implications for access to the Japanese market? Do Japanese financial keiretsu allow more monopoly power in Japanese manufacturing activity than there is in American or European manufacturing, and does this consequently limit foreign access to the Japanese market, thereby affecting the welfare of Japanese consumers and international producers in a way that distinguishes corporate behaviour in Japanese markets from that in other industrial countries? Does the presence of vertical keiretsu lead to exclusion of competitive foreign suppliers from the Japanese market for manufactures? Does the prevalence of distribution keiretsu lock out competition in final or intermediate goods markets?

\section{Financial keiretsu and competition}

The suggestion that financial keiretsu are harbingers of monopoly power to a peculiar extent can be dispatched quickly. As the literature on industrial organisation makes clear (Jacquemin and Slade, 1989; Tirole, 1988), cartels or anti-competitive and collusive practices involve price-fixing or coordination in the same product markets. Firms in Japanese financial keiretsu (and, for that matter in vertical or distribution keiretsu) cannot collude or form cartels by virtue simply of their keiretsu affiliations because keiretsu firms from the same group do not operate in the same product market. Financial 
keiretsu are sometimes described as 'horizontal' structures, but they are not in the sense in which the term horizontal (as in 'horizontal merger') is used in the literature on industrial organisation. They are horizontal structures only in the sense in that they involve operations in different product markets across a whole range of corporate activities. This is the 'one-set' phenomenon identified by Miyazaki (1967).

The fact that there are six major financial keiretsu in Japan, it might reasonably be argued, intensifies competition in different product markets rather than reduces it. Participation in most markets is high and the threat and ease of entry great. These keiretsu groups, as well as independent firms, are players in most important markets which are consequently less concentrated than markets in many other industrial countries. Moreover, the trading companies, which are a mainstay of financial keiretsu, are very competitive and active in each other's markets. There are particular markets characterised by a large degree of concentration and monopoly or oligopolistic behaviour in Japan and it is also theoretically conceivable, but not practically credible (Sheard, 1994, pp.7-18), that keiretsu groups may facilitate multi-market collusion (Tirole, 1988). But most studies of market concentration across industrial countries do not reveal Japan as an outlier (Caves and Uekusa, 1976). Indeed, for most sectors, market concentration is relatively low in Japanese manufacturing. There are nine automobile producers in Japan in contrast to the big three in the United States, and while concentration ratios have limited value as an indicator of competition in product markets, the Japanese automobile industry, for example, appears intensely competitive (Smitka, 1991).

Sheard (1994, p.16) exposes the confusion in the literature on keiretsu, competition and market access in Lawrence's influential study (1991a). Lawrence concludes (p.329):

While antitrust motivations should be punished, there are cases where keiretsu relationships improve efficiency. As might be expected, these efficiencies tend to be associated with vertical rather than horizontal linkages. Given the complexity and pervasiveness of vertical keiretsu, it is difficult to support extreme approaches that would either entirely ban these linkages or outwardly tolerate them. Instead 
vigilance and a "rule of reason" approach, which pays a particular attention to horizontal linkages, seems more appropriate.

The horizontal linkages Lawrence has in his sights here, as Sheard points out, have nothing to do with monopoly potential, but are cross-market, rather than within-market, conglomerate-like structures involving vertical linkages in the sense of the literature on industrial organisation. Financial keiretsu do not offer scope in themselves for collusion and exclusionary market practices in the way that policy discussion and policy-driven academic discussion suggests.

\section{Vertical keiretsu and market access}

Most of the political rhetoric and policy energy surrounding the keiretsu issue focuses on the way in which vertical keiretsu are said to discriminate against 'outsiders'. There is a large number of anecdotes from journalists, businessmen and politicians about 'cosy relationships' between upstream and downstream producers in almost every part of manufacturing. These anecdotes are about discriminatory or preferential vertical relationships in the market for intermediate goods and supplies.

There are two puzzles about the claim that long term contracting in vertical keiretsu discriminates against competitive foreign suppliers of intermediate products in Japanese manufacturing. The first has to do with why Japanese assembly firms, like automobile manufacturers, would wish to handicap themselves by maintaining inefficient suppliers when they have to operate in a competitive international final product market. In the industrial organisation literature, this observation relates to the 'rule of reason' that vertical relationships are acceptable provided that the relationships are formed in contestable markets. This does not mean that such markets adjust immediately to new competitive pressures. Indeed, such corporate dealings may contain a conservative bias, delaying the emergence of intermediate goods imports beyond the time when they initially appear to have become competitive (Drysdale, 1969; Saxonhouse, 1988, p. 234; Drysdale and Garnaut, 1993). But such lags in the process of market adjustment are not unique to 
Japanese corporate structures. It took several years for German and Japanese steel producers to sell their cheaper steel to General Motors in the United States after American steel became uncompetitive (Drysdale, 1989). As Cooper's (1975) study of North American markets for metals in the 1970s shows us, the lagged response to relative price change is an appropriate response in dynamic and competitive markets. Long term contracting has a similar effect in the Australian resource trade (Smith, 1979).

The second puzzle is why vertical relationships - which would attract no attention in trade practice law and policy if they were conducted within fully integrated corporate operations - are an object of policy interest if practiced between two firms that are not fully integrated. General Motors' purchases 25 percent of its imports from outside suppliers, compared with Toyota's outside purchases of some 75 percent (Aoki, 1986). Why, asks Saxonhouse (1993, p.38), is formal vertical integration in the United States better (or fairer) than informal integration in Japan? In fact, it may be less efficient as well as no fairer, as trends in North America in the last decade or so seem to confirm (Smitka, 1991; Smitka 1993). Dyer (1993) provides data suggesting that Japanese automobile parts markets are as open to arms-length supply as those in the United States. As Weinstein and Yafeh (1993) demonstrate, the higher the proportion of keiretsu firms in a Japanese industry, the lower the price-cost margins, a phenomenon consistent with intense competition among keiretsu groups.

There is an extensive analytical literature on discriminatory vertical relationships in industrial organisation (Perry, 1989). The findings in the literature support skepticism about such relationships being instruments of collusive behaviour: as Sheard (1994) observes, what to outsiders may appear as 'cosy relationships' may be characterised alternatively as 'value adding partnerships' (Johnston and Wallace, 1988).

The central question is whether vertical keiretsu are plausibly cast as instruments of market foreclosure, where a firm at one stage of production 'closes off' another stage of production to its rivals (Sheard, 1993; Sheard, 1994): 
Vertical foreclosure can take two forms, depending on whether the purchasing firm is upstream or downstream. Downstream foreclosure occurs when an upstream firm enters into contracts with downstream firms with the aim of shutting out other upstream firms from the output market (the downstream input market). Upstream foreclosure occurs when a downstream firm enters into contracts with upstream firms with the aim of disadvantaging other downstream firms in its output market by raising the costs of supply of inputs $\Leftarrow \mathrm{a}$ traditional concern in the anti-trust literature involves the case of a downstream monopolist foreclosing entry to its market by denying the potential entrant access to an essential input that it controls (Sheard, 1994, p.24).

The concern about foreclosure through vertical keiretsu would be relevant, as Sheard (1994) also points out, only under very unlikely circumstances. Downstream foreclosure would require, for example, that suppliers of inputs like steel or glass in the automobile industry tried to exercise market power by locking up downstream automobile producers' input markets against other suppliers of steel or glass, domestic or foreign. It is hardly probable that it will be in the interests of automobile manufacturers to allow upstream firms to monopolise their input markets, potentially raising their costs and lowering quality and competitiveness. Technically, this is not a Nash equilibrium and so is an unlikely outcome - parties to this type of agreement have incentives not to abide by it. The other possibility is upstream foreclosure by Japanese automobile manufacturers. This strategy would aim at excluding rivals from supply networks, but the issue of Toyota or other Japanese auto-makers denying American makers access to their affiliated suppliers so that American maakers are disadvantaged is not an issue that is really on the agenda.

Firms enter into long term contracts in competitive markets because they generate value - lowering costs, improving quality, securing supply channels - through doing so. The way in which a firm organises its input purchases is an important choice in a market economy. It is one of the decisions to be made about using corporate resources and strategic opportunities. Manufacturers compete with one another more or less successfully in this dimension as in others. To represent this process in terms of closure of markets is misleading. 


\section{The distribution system}

The arguments about the way in which the Japanese distribution system limits access to the Japanese market may have more substance. Yet, here too, it is important to distinguish the effect of distribution keiretsu from other factors affecting access in final goods markets.

The analysis of potential foreclosure in the distribution of final or intermediate products is analogous to the case of intermediate product markets: if 'distribution' is seen as another kind of input used in delivering output. From this perspective, the distribution system presents an opportunity for upstream foreclosure by Japanese manufacturers using distribution channels to disadvantage domestic and foreign competitors by denying them access to a needed input. This is the essence of the United States complaint about restraints in marketing American automobiles in Japan.

Because distribution has many of the characteristics of a non-traded good - at least some of the inputs must be acquired locally - there may appear a special opportunity for foreclosure in this market. However, the conditions under which foreclosure will succeed are strict in theory (Hart and Tirole, 1990) and remote in practice (Sheard, 1994, pp. 27-28). There is always the option of a firms mobilising its own distribution facilities - presuming the right of establishment and entry. If the right of establishment and entry is denied, that is likely a problem of the regulatory system, not a problem of the corporate structures involved.

Moreover, and more tellingly, downstream firms will have an incentive to enter contracts with upstream suppliers of final products only if such contracts lower their costs, or enforce quality in delivery, and only so long as other upstream suppliers (including those from abroad) cannot supply a competitive alternative.

In the automobile market, this circumstance will be recognised by Australian readers familiar with the entry of Japanese suppliers into the Australian passenger vehicle markets in the 1960s and 1970s. As the competitiveness of Japanese automobiles was established, exclusive dealerships for the products of American owned firms crumbled, but only after a time. 
There are other more important reasons why American trade negotiators put much effort into opening up Japan's distribution system. Regulatory controls, not distribution keiretsu, limit outlets and increase distribution costs for a range of products both domestic and foreign. Hence, reform of Japan's Large Scale Retail Store Law was an important target in the Structural Impediments Initiative negotiations (Terada, 1994). The effect of these regulatory controls is formidable and embedded in social structures (such as the appeal of 'mom and pop stores' in retailing) so that inertia to reform and change may be great.

\section{An Australian connection}

Australian policymakers and corporations with extensive dealings in Japan are knowledgeable about the restrictions and regulatory systems that affect access to the Japanese market, especially over a wide range of the agricultural and services trades. Australia is not a leading exporter of manufactures to Japan, although Japan is Australia's second largest single export market for manufactured goods after New Zealand (APEG, 1995). New entrants to the Japanese market, for example, manufacturers of vehicle components, are familiar with the time-consuming processes involved in establishing a beachhead and market share. ${ }^{4}$ But, significantly, the issues of corporate behaviour and practice reviewed in this paper have not been conspicuous in Australian business or policy discussion of access to the Japanese market.

Yet, oddly, there is an important Australian connection in the literature. The purchasing behaviour of Japanese firms in Australia has been cited prominently to substantiate the claim that Japanese practices are exclusionary, limiting access by foreign suppliers to Japanese companies at home and abroad (Lawrence, 1991b, p.21). ${ }^{5}$

\footnotetext{
${ }^{4}$ One Australian manufacturer of components for the vehicle industry reported to me a requirement that his consignment to Japanese agents be delivered in non-branded packaging so as to disguise the switch in purchases by assemblers (Interview, Sydney, 1994).

${ }^{5}$ The material in this section is drawn from Drysdale, 1993.
} 
The principal evidence on this matter is presented in a survey by Kreinin (1989) of sixty-two companies in Australia, of which twenty were Japanese, twenty-two were American, and twenty were European. On the basis of responses to his questioning, he suggests that Japanese subsidiaries in Australia 'are highly controlled by the respective parent company, procure their equipment mainly from Japan and use and operate mainly Japanese machinery' (Kreinin, 1989, p.540). Kreinin's conclusion is very strong and his interpretation of his findings unequivocally links this behaviour to peculiar Japanese corporate practice. His work is cited widely in policy circles in the United States and provided early credence to the notion that keiretsu corporate structures constituted a major 'hidden' barrier in accessing the Japanese home market. ${ }^{6}$ Yet his questionnaire appears open-ended, there is no summary statistical reporting of his findings whereby it is easy to assess his impression of the evidence, and he makes no comparison between his findings and those of others, including the regular surveys by responsible Japanese and American agencies.

Kreinin reports that in fifteen out of twenty Japanese companies surveyed, either all or over 80 percent of the equipment was of Japanese origin (p.535). Only five firms used international competitive bids for purchasing standardised equipment, compared with twenty-one of the twenty-two American-owned subsidiaries for machinery or materials not available for Australia. He did note that a few Japanese firms intended to move to open tendering but this observation did not qualify the interpretation of his findings. Kreinin's study of Japanese foreign direct investment in Australia is consistent with the general impression of Japanese corporate use of its own suppliers of parts and components in Japanese investments elsewhere, in North America and East Asia.

\footnotetext{
${ }^{6}$ Kreinen's study is cited as justification for import targeting policy strategies by American officials (Interview, USTR, December 1990).
} 
There is a valuable reference point to Kreinin's work and general impressions in the classic study of American investment in Australia by Brash (1966). Brash undertook a careful survey of the sales and purchasing of American investors in Australia in 1962. Interestingly, Kreinin appears unaware of Brash's earlier study or its relevance to his own work.

Brash's work reveals that American subsidiaries he surveyed were unlikely to purchase equipment or components from Australian suppliers, even if they were cheaper than equipment and materials sourced from affiliated or parent companies (pp.203-211). Most of the imports of American-owned companies were purchased from or through American affiliated firms with wholly owned firms having a higher dependence on imports than joint ventures. Significantly, Brash's data (p. 205) suggest that the more recently established American subsidiaries imported a much higher proportion of their equipment and material requirements than older established firms. Measured as a proportion of total sales (rather than purchases, for which data was not readily available), the import ratio for all firms was 18.7 percent, but for firms established in the previous five years it was 29.5 percent.

On the basis of both the impressionistic and the more comprehensive statistical evidence that Brash provides on American subsidiary purchasing behaviour in Australia, it would seem difficult to conclude that Japanese firms differ significantly in this respect from their American counterparts. There is, in fact, a deal of published quantitative evidence that can be turned to analysing the purchasing behaviour of Japanese and, to a lesser extent, American subsidiaries in Australia. I have reviewed this evidence in some detail elsewhere (Drysdale, 1993, pp. 33-34). ${ }^{7}$

It is clear from this evidence that Japanese subsidiaries imported a higher proportion of intermediate goods and equipment from the home country than their

\footnotetext{
${ }^{7}$ A recent study by Nicholas (1995) provides a rich new source of data on the characteristics and behaviour of Japanese affiliates in Australia.
} 
American counterparts in the 1980s. It is also clear that there was a significant change in the pattern through the decade. Imports from Japan were consistently and significantly declining as a proportion of intermediate goods purchases over these years. Whatever drives this pattern of purchases, it is not a permanent feature of Japanese corporate behaviour.

Kreinin's findings can be explained rather on grounds that have little to do with discriminatory or exclusionary practices by Japanese firms or keiretsu corporate structures (Saxonhouse, 1991). Most Japanese manufacturing operations in Australia are of recent origin. The bulk of these investments in the past were designed to produce substitutes for products that were previously imported to Australia from Japan. Japan continues to have a strong comparative advantage in what Japanese affiliates in these sectors are producing in Australia (in automobiles, for example). By contrast, most of the American and European firms with which Kreinin makes comparison are decades old, producing goods in which the home country has lost much of its comparative advantage. It is hardly surprising that the sourcing pattern of Japanese manufacturing firms in Australia is as it is. This has historically been typical also of the sourcing patterns of American manufacturing firms in Australia. The evidence reinforces Saxonhouse's observation that Kreinin's Australian study is entirely consistent with the histories of multinational corporations more generally (Wilkins, 1975; Chen and Drysdale, 1995). It does not suggest distinctive Japanese trade practices. This issue is endemic in the experience of multinational corporations and host countries as is attested to by the prevalence of local content requirements in the national regulation of direct foreign investment throughout the world.

\section{Implications for policy}

This paper set out to explore how market structure and different corporate organisational forms might affect access to the Japanese market for manufactured goods. The argument that keiretsu corporate structures in Japan are collusive and exclusionary 
has been used to justify American trade policy strategies, such as calling for import targets in Japanese markets for manufactured goods, which would treat Japan differently from other industrial countries and seek to manage trade flows in ways which are not consistent with the principles to which GATT has appealed in the past and which are embodied in the WTO.

This is no trivial issue. American trade policymakers pushed this argument strongly in the recent attempt to 'open' Japanese automobile and automobile parts markets. Significantly, there was widespread unease in international policy circles about this American trade policy approach. This paper provides argument which reinforces this unease.

Keiretsu corporate structures are not accurately characterised as 'collusive', 'cartel-like', 'anti-competitive' or 'exclusionary' in the antitrust sense of the term'. Financial keiretsu are more likely to increase competition in final product markets than they are to reduce it, other things being equal. Vertical keiretsu reflect efficient relational dealings in intermediate product markets rather than restrictive trade practices. Even in the case of distribution keiretsu, an area of more concern on the surface of it, vertical foreclosure is not the main issue. The main issue is regulatory controls which inhibit or facilitate entry to final product markets, and they are the relevant target of policy attention.

The argument for trade policy strategies which seek to break down 'hidden barriers' to trade, resulting from keiretsu corporate structures, through the imposition of import targets and managed trade arrangements is intellectually flawed built on loose logic and incomplete information about the nature of the institutional arrangements which are the object of policy. If Japanese policymakers had yielded to this argument, Japan would, incidentally, have signed on to a policy of re-regulation against

\footnotetext{
${ }^{8}$ As Sheard (1994, p.32) points out, the notion of 'exclusion' as an aspect of long term contracting or the dynamics of repeated transactions needs to be carefully distinguished from 'exclusion' in the context of antitrust.
} 
the thrust of domestic and international interest in Japan's liberalisation and economic reform agenda.

This is not, of course, to suggest that there are not problems of access to the Japanese market for manufactured goods. In some industries, industry associations provide a potential vehicle for collective practices. Regulatory systems impact on these markets, as they do on other markets in Japan, such as in the agricultural and services sectors. However, the direct effect of regulatory systems on manufactured goods markets is circumscribed. For example, in the case of automobile product markets, American negotiators focused attention on Japan's motor vehicle inspection system (shaken) as a restraint on import trade. The inspection agency arrangements effectively cut suppliers of imported parts out of the market. This provides ground for legitimate complaint and is accepted as such by Japanese negotiators. These regulations affect foreign supplier access and the welfare of Japanese consumers. In the Section 301 move on the automobile products trade against Japan, American officials (Kantor, 1995a) were careful to confine the formal complaint, which triggered action, largely to the issue of the so-called 'afterparts' market for automobile products. But this market is tiny in relation to the entire automobile products market, control over which was more broadly and publicly contested between Japan and the United States (Kantor, 1995b; Clinton, 1995).

Here, there is not the space to analyse developments in trans-Pacific automobile products trade in detail. Suffice it to observe that this market will undergo further rapid charge over the next decade, as it has over the past decade; that there will be a significant increase in Japan's intra-industry trade, as the competitiveness of manufacturing automobiles in Japan peaks and Japanese firms adjust to the new competitive circumstances of their operations in Japan, North America and elsewhere; and that these changes will be largely driven by competitive forces in the market, not by policy posture in North America.

Markets that appear closed to new entrants because of keiretsu corporate ties are markets that need to be opened by business, not government negotiators. Japanese firms have no sensible interest in sheltering their suppliers from foreign competition. They do 
not need Japanese or US government officials to guide them to make cost-minimising import purchase decisions. There may be good reasons to increase foreign access to the Japanese market. The justification for these actions, however, must lie in other than the anti-competitive and market foreclosure rhetoric in which it is clothed (Sheard, 1994, p.41).

It needs to be added, nonetheless, that the threat of reprisals and aggressive unilateral trade policy action by the United States can have impact, however flawed its intellectual foundations. Australian exports of vehicles and components to Japan have been stagnant over the past year while imports from other sources in Europe, and even North America, have grown. ${ }^{9}$ This may be simply a product of the structure of import adjustment during a deep recession. On the other hand, it could also be related to the gathering threat of American trade action. Detailed analysis is needed to assess whether American trade policy threats affected procurement strategies by the Japanese industry over this period and what effect they might have in the future. There is enough circumstantial evidence to warrant active research interest in this area.

\footnotetext{
${ }^{9}$ Japanese imports of Australian-made motor vehicles and components fell by 8 percent between April 1994 and March 1995, while imports from the United States grew by 53 percent. Imports from all sources grew by 35 percent. Imports of Australian-made components fell by 13 percent, while imports of American-made components increased by 22 percent. Australia's exports of motor vehicle parts and components to Japan were \$A207.4 million in 1994, in total exports of these products of \$A1.54 billion. (Data on imports of automobile products into Japan are from Nikkei Telecom Database, Australia-Japan Research Centre, and data on Australian exports are from the Australian Bureau of Statistics.)
} 


\section{References}

Abbeglen, J. and Stalk, Jr, G. (1985) Kaisha: The Japanese Corporation, Tokyo: Charles E. Tuttle.

Advisory Committee for Trade Policy and Negotiations (ACTPN) (1993), Major Findings and Policy Recommendations on US-Japan Trade Policy, Washington D.C., January.

Alchian, A. and H. Demsetz (1972) 'Production, information costs, and economic organization', American Economic Review, Vol. 77, pp. 388-401.

Altman, R. (1994) 'Why pressure Tokyo?', Foreign Affairs, Vol. 73 (3), May/June.

Aoki, M. (1986) 'Horizontal vs. vertical information structure of the firm', American Economic Review, Vol. 76, pp. 971-83.

Aoki, M., H. Patrick and P. Sheard (1994) 'The Japanese main bank system: an introductory overview', in M. Aoki and H. Patrick (eds) The Main Bank System: Its Relevancy for Developing and Transforming Economies, Oxford: Oxford University Press.

Asia Pacific Economics Group (APEG) (1995) Asia Pacific Profiles, The Australian National University.

Balassa, B. (1986) ‘Japan’s trade policies’ Weltwirtschaftliches Archiv, 122, pp. 754-90. 
Balassa, B. and M. Noland (1988) Japan in the World Economy, Washington D.C.: Institute for International Economics.

Bergsten, C.F. and M. Noland (1993), Reconcilable Differences?, Washington D.C.: Institute for International Economics.

Bhagwati, J. (1994) 'Samurais no more' Foreign Affairs, 73 (3), May/June.

Brash, D. (1966) American Investment in Australian Industry, Canberra: Australian National University Press.

Caves, R. and M. Uekusa (1976) 'Industrial organization' in H. Patrick and H. Rosovsky (eds) Asia's New Giant: How the Japanese Economy Works, Washington D.C.: The Brookings Institution.

Chen, E. and P. Drysdale (eds) (1995) Corporate Links and Foreign Direct Investment in Asia and the Pacific, Sydney: HarperEducational.

Cheung, S. (1983) 'The contractual nature of the firm', Journal of Law and Economics, Vol. 26 (1), pp. 1-21.

Clinton, W. (1995) White House statement on Japanese trade talks, 28 June.

Coase, R. (1937) 'The nature of the firm' Economica, n.s. 4, pp. 386-405.

Cooper, R. (1975) 'Natural resources and national security', Resources Policy, 1 (4), June. 
Dore, R. (1986) Flexible Rigidities: Industrial Policy and Structural Adjustment in the Japanese Economy 1971-80, Stanford: Stanford University Press.

Drysdale, P. (1969) 'Japan, Australia and New Zealand: The prospects for Western Pacific economic integration', Economic Record, Vol. 45 (111) September pp. 321-42.

_ (1989) 'Japan's trade diplomacy: yesterday, today, tomorrow' Pacific Economic Papers, No. 178, December.

_ (1993) 'Japanese direct foreign investment in Australia in pomparative perspective', Pacific Economic Papers, No. 223, September.

Drysdale, P. and R. Garnaut (1993) 'The Pacific: An application of a general theory of economic integration', in C.F. Bergsten and M. Noland (eds) Pacific Dynamism and the International Economic System, Washington D.C.: Institute for International Economics.

Dyer, J. (1993) 'The Japanese vertical keiretsu as a source of competitive advantage', mimeo, University of Pennsylvania.

Fama, E. (1980) 'Agency problems and the theory of the firm', Journal of Political Economy, 88, pp. 288-307.

Fruin W.M. (1992) The Japanese Enterprise System: Cooperative Structures and Competitive Strategies, Oxford: Clarendon Press.

Fung K.C. (1991) 'Characteristics of Japanese industrial groups and their potential impact on US-Japan trade', in R. Baldwin (ed) Empirical Studies of Commercial Policy, Chicago: The University of Chicago Press. 
Gerlach, M. (1992) Alliance Capitalism: The Social Organization of Japanese Business, Berkeley: University of California.

Gibson R. and M. Roe (1993) 'Understanding the Japanese keiretsu: overlaps between corporate governance and industrial organization', Yale Law Journal, 102, pp. 871-906.

Goto, A. (1982) 'Business groups in a market economy', European Economic Review, Vol. 19, pp. 53-70.

Goto, F. (1991) 'Is the Japanese market really closed? a critical review of the economic studies', Studies in International Trade and Industry, No. 8, Tokyo: Research Institute of International Trade and Industry.

Hart, O. and J. Tirole (1990) 'Vertical integration and market foreclosure', Brookings Papers: Microeconomics 1990, pp. 205-276.

Hashimoto, R. and M. Kantor, (1995) Joint announcement regarding autos and auto parts, 28 June.

Horiuchi, A., F. Packer and S. Fukuda (1988) 'What role has the "main bank" played in Japan?' Journal of the Japanese and International Economies, Vol. 2 (2) June, pp. 159-80. 
Jacquemin, A. and M. Slade (1989) 'Cartels, collusion and horizontal merger', in R. Schmalensee and R. Willig (eds) Handbook of Industrial Organization, Vol. 1, Amsterdam: North Holland, pp. 415-473.

Jensen, M. and W. Meckling (1976) 'Theory of the firm: Managerial Behavior, Agency Costs and Ownership Structure', Journal of Financial Economics, 3 (4), pp. $305-60$.

Johnston, K. and P. Wallace (1988) 'Beyond vertical integration: the rise of the value-adding partnership', Harvard Business Review, July-August, pp. 94-101.

Kantor, M. (1995a) 10 May, US to file WTO Trade Complaint Against Japan Auto Policy, Press Statement

Kantor, M. (1995b) Text of press conference, 28 June.

Keizai Chosa Kyokai (1992) Nenpo 'Keiretsu no kenkyu' daishu (1992) Daiichibu jojo kigyohen, No. 32

Kreinin, M. (1989) 'How closed is the Japanese market? Additional evidence', The World Economy, Vol. 11 (4), pp. 529-42.

Kravis, I. B and Lipsey, R. E (1971), Price Competitiveness in World Trade, NBER, Columbia, New York.

Krugman, P. (1991) 'Introduction', in P. Krugman (ed.) Trade with Japan: Has the door opened wider?, Chicago: The University of Chicago Press. 
Lawrence, R. (1987), 'Imports to Japan: Closed markets or closed minds?', Brookings Papers on Economic Activity, Vol. 2, pp. 517-52.

_ (1991a) 'Efficient or exclusionist? The import behavior of Japanese corporate groups', Brookings Papers on Economic Activity, Vol. 1, pp. 311-341.

(1991b) 'How open is Japan?', in P. Krugman (ed) Trade with Japan: Has the door opened wider?, Chicago: The University of Chicago Press.

_ (1993), 'Japan's different trade regime: An analysis with particular reference to keiretsu', Journal of Economic Perspectives, Vol. 7 (3), Summer, pp. 3-19.

McMillan, J. (1990) 'Dango: Japan's price fixing conspiracies', Economics and Politics, 3 (3), pp. 201-18.

Miyazaki Y. (1967) 'Rapid economic growth in post-war Japan: with special reference to "excessive competition" and the formation of "keiretsu", The Developing Economies, Vol. 5 (2), pp. 329-350.

Nicholas, S. (1995) 'Japanese investment in Australia: the investment decision and control structures in manufacturing, tourism and financial services', Public Seminar, Australia-Japan Research Centre, 17 July.

Passell, P. (1989) 'Economic scene: managed trade or open trade?', The New York Times, 5 April. 
Perry, M. (1989) 'Vertical integration: determinants and effects', in R.

Schmalensee and R. Willig (eds) Handbook of Industrial Organization, Vol. 1, Amsterdam: North Holland, pp. 183-255.

Robinson, J. and J. Houghton (1989) Analysis of the US-Japan Trade Problem, Report of the Advisory Committee for Trade Policy and Negotiations, Washington D.C., February.

Sazanami, Urata, and Kawai (1995), Measuring the Costs of Protection in Japan, Institute for International Economics, Washington DC.

Saxonhouse, G. (1986) 'What's wrong in the Japanese trade structure?', Pacific Economic Papers, No. 137, July.

- (1988) 'Differentiated products, economies of scale and access to the Japanese market', Seminar Discussion Paper No. 288, Research Seminar in International Economics, University of Michigan.

_ (1991) 'Comment' in P. Krugman (ed) (1991) Trade with Japan: Has the door opened wider?, Chicago: The University of Chicago Press.

_ (1993) 'What does Japanese trade structure tell us about Japanese trade policy?' Journal of Economic Perspectives, Vol. 7(3), Summer, pp. 21-43.

Saxonhouse, G. and R. Stern (1989) 'An analytical survey of formal and informal barriers to international trade and investment in the United States, Canada and 
Japan', in R. Stern (ed) Trade Relations Among the United States, Canada, and Japan, Chicago: The University of Chicago Press.

Sheard, P (1986) Corporate Organisation and Structural Adjustment in Japan, $\mathrm{PhD}$ thesis, The Australian National University.

(1988) 'On the economic organization of the firm', Seminar, Department of Economics, 25 February.

- (1991) 'The economics of Japanese corporate organization and the "structural impediments" debate: a critical review', Japanese Economic Studies, Vol. 19 (4), pp. 30-78.

_ (1993) 'Keiretsu and closedness of the Japanese market: an economic appraisal', Working Paper Series No. 93-5, Centre for Japanese Economic Studies, Macquarie University, April.

- (1994) 'Keiretsu, competition, and market access', Discussion paper 94-17, Osaka University: Faculty of Economics, December.

Ben Smith (1979), 'Security and Stability in Mineral Markets: The Role of Long Term Contracts', in The World Economy, Vol.2, No.1, January.

Smitka M. (1991) Competitive Ties: Subcontracting in the Japanese automobile industry, New York: Columbia University Press. 
_ (1993) 'The decline of the Japanese auto industry: domestic and international implications', paper for The Japan Economic Seminar, East Asian Institute, Columbia University, New York, February.

Terada, T. (1994) 'Political economy of the large-scale retail store law:

transforming 'impediments' to entering the Japanese retail industry', Pacific

Economic Papers, No. 237, November.

Tirole, J. (1988) The Theory of Industrial Organization, Cambridge MA: The MIT Press.

Toyo Keizai Shimposha (1991) Kigyo keiretsu soran 1992 Nenban [Corporate affiliation directory], Tokyo.

United States Department of Commerce and Japan Ministry of International Trade and Industry (1989) The Joint DOC/MITI Price Survey: Methodology and Results, Washington D.C., December.

United States Trade Representative (USTR) (1995) National Trade Estimates, Washington D.C.

Warren, T. (forthcoming) The Political Economy of Services Trade Policy: Australia, Japan and the United States, $\mathrm{PhD}$ thesis, The Australian National University. 
Weinstein and Yafeh (1993) 'Japan's corporate groups: collusive or competitive? An empirical investigation of keiretsu behavior', Harvard Institute of Economic Research Discussion Paper No. 1623, Harvard University.

Wilkins, M. (1975) The Maturing of Multinational Enterprise: American Business Abroad, 1914-1970, Cambridge MA: Harvard University Press.

Williamson, O. (1975) Markets and Hierarchies: Analysis and Antitrust Implications, New York: Free Press.

_ (1985) The Economic Institutions of Capitalism, New York: Free Press. 